\title{
Before the 'locomotive' runs: the impact of the I973-I974 oil shock on Japan and the international financial system
}

\author{
KAZUHIKO YAGO \\ Waseda University
}

\begin{abstract}
This article offers a Japanese perspective on the debate about the international financial system immediately after the first oil shock of 1973-4. Using archival records from the OECD and Bank of Japan, I analyze the three key policy issues discussed at the meetings of Working Party $3\left(\mathrm{WP}_{3}\right)$ of the OECD: petrodollar recycling, balance-of-payments adjustments, and the management of global growth. Documents show that the Japanese approach to capital controls, exchange rate management, state-led growth orientation and international banking strategies was rather strengthened by the impact of the oil shock. By 1975 the OECD viewed Japan, together with Germany and the United States, as one of the 'locomotives' that would trigger a revival of economic growth in the industrialized West.
\end{abstract}

Keywords: petrodollars, recycling, balance-of-payment adjustment, OECD, Japan

JEL codes: $\mathrm{F}_{32}, \mathrm{~F}_{42}, \mathrm{~N}_{10}, \mathrm{~N}_{15}, \mathrm{~N}_{2} \mathrm{O}$

The oil shock of the I970s is considered one of the most momentous events in the transformation of the world economy, along with the Nixon shock (Maier 2004). The fourfold increase in the oil price (from $\$ 2.90$ to $\$$ II.65 per barrel between October I973 and January I974) caused by the Organization of Petroleum Exporting Countries (OPEC) shook the foundations of capitalist economies, which until then had enjoyed a plentiful supply of cheap oil under a fixed exchange rate regime. In the longer run, the oil shock brought about huge flows of dollars to oil-rich exporters in the Middle East, which recycled their excess international liquidity to the industrialized West. This 'petrodollar recycling' stimulated the rise and deregulation of the Eurocurrency market as well as the liberalization of capital movements championed by American bankers (Cassis 2006). Those outcomes, later on, would pave the way for the rise of the neoliberal economic and political paradigm,

K. Yago, Professor of Economic History, School of Commerce, Waseda University, I Chome-I04 Totsukamachi, Shinjuku City, Tokyo I69-8050, Japan; email: yago@waseda.jp. This research was supported by JSPS KAKENHI grant no. I7Ho2556 and a Mitsubishi Foundation grant (2019-20). 
on the one hand, and the revival of European economic integration after years of Euro-skepticism, on the other (Beltran 20I I; Gfeller 2012; Beltran et al. 2016; Bini et al. 2016).

This historical process, from the oil shock to the liberalization of international financial markets, is one of the most fertile fields of study in financial history. Two excellent recent works are worth citing. Selva (20I7) analyzes petrodollar recycling in the context of the US foreign financial policy, tracing continuous attempts by the US to regain global financial hegemony. Freer capital movements, together with energy finance and development aid, strengthened US banks' position and prepared the 'neoliberal turn' of the early ig8os. Altamura (20I6) examines the role of petrodollar recycling in the evolution of the Eurodollar market, focusing on the policy debates over the regulation of the international money market. This debate, which took place in international organizations such as the Bank for International Settlements (BIS), was settled by the victory of free marketeers, eager to make use of the market as an important channel for the recycling of international liquidity. Both studies stress the key role played by private international banks as well as the decision taken by public authorities, either at state level or by international organizations.

However, one important link is missing in the literature about the oil shock and its financial aftermath: Japan. In fact, the path taken by Japan before and after the shock differed from both the American and West European experiences. Japan, whose industrialization had been heavily dependent on coal energy, had quickly accomplished the energy transition from coal to oil during the I960s (Kobori 2010). Since then, Japan has relied on imported oil, mainly from the Middle East, for its energy needs. The remarkable growth of the Japanese economy during the Ig6os surprised the Americans and the Europeans, and Japan was allowed to join the Organization for Economic Cooperation and Development (OECD) in I964 (Winand I993; Suzuki 20I3). In the turmoil caused by the Nixon shock, Japan successfully abandoned the Bretton Woods system of adjustable peg and adopted a floating exchange rate, thanks to sustained global growth during 1972-3, although its overdone monetary stimulus was followed by furious inflation (Eichengreen and Hatase 2007). In the summer of I976, Japan, together with West Germany and the United States, was asked by the OECD Secretariat to play the role of 'locomotive' to trigger a growth revival in the industrialized West. As such, Japan made 'a sound contribution to stable and non-inflationary growth in the world economy' (Hollerman 1979). The Tokyo capital market grew up 'around government bonds that the authorities began to issue from 1975 to finance a budget deficit' due to the oil crisis (Cassis 2006). On the other hand, Japan remained reluctant to deregulate its capital market until the I980s and tried to avoid a re-evaluation of the yen up to the arrival of the bubble economy in the late I980s (Asai 2015).

This article offers a Japanese perspective on the debate about the international financial system immediately after the oil shock, comparing it with the American and West European strategies. The main forum of debates to be dealt with is the OECD, especially its Working Party $3\left(\mathrm{WP}_{3}\right)$. The $\mathrm{WP}_{3}$ was an unofficial but 
powerful forum for coping with problems of balance-of-payments adjustment. It naturally became one of the most important bodies for policy discussion about petrodollar recycling, international payments and global growth after the oil shock (Van Lennep I998; Galeazzi 2015; Yago 2017). Since its foundation in I961, the OECD had aimed at planning economic growth of the West, setting a target of ' 50 percent GNP growth in ten years for member countries', in response to the slowdown of growth in the capitalist world of the late I950s. Since then, managing the macroeconomy with 'target' and 'aims' goals became common practice among international institutions (Schmelzer 2016; Leimgruber et al. 2017). The reaction of industrialized countries to petrodollar recycling, and in particular the Japanese strategy after the oil shock, was built upon this 'growth paradigm' represented by the OECD.

Using the archival records of the OECD and the Bank of Japan, the article asks three sets of questions:

(I) Which recycling channels were favored by the OECD and Japanese authorities? Which market or institution played the most important role in recycling? How did Japan assess the outcome?

(2) How did OECD countries adjust the balance-of-payments disequilibrium? How did Japan, as a surplus country, react to the adjustment?

(3) How did national and international actors produce a grand scheme for global growth after the oil shock? Which role was Japan expected to play in this context?

Section II overviews the reaction of OECD and Japan to early increases in the oil price from the late I960s to October I973, before the arrival of the proper oil shock of I973-4. Section III deals with the debate on petrodollar recycling from October I973 to mid I974, focusing on the Eurocurrency market and US banks. Section IV considers the aftermath of the crisis and the rise of 'locomotive' ideas in the OECD's $\mathrm{WP}_{3}$. Section $\mathrm{V}$ concludes.

The outbreak of the oil crisis caused a frenzied reaction by OECD countries and Japan. The OECD had convened a Special Oil Committee in June I967, immediately after the end of the Third Arab-Israeli War (also known as the Six-Day War), to discuss emergency measures to be taken in oil-importing countries. The discussions, however, revealed an antagonism between the United States, which advanced the possibility of emergency oil rationing, and France, which was opposed to such a harsh measure. Japan, lying between the two opinions, kept silent: the Japanese Ministry of Foreign Affairs instructed its representative at the OECD 'not to support any proposals actively'. The Japanese position derived from the fact that Japan maintained a neutral stance between the Arabs and Israel in order to avoid an embargo. 'From a longer perspective, cooperation with the US is essential', noted the Japanese representative at the OECD, 'from a shorter perspective, we could secure oil supply' (Shiratori 2015, p. 48). 
After a pause of a few years, the oil price again entered a stormy phase in the early I970s. How did the $\mathrm{WP}_{3}$ assess the situation? In February I973, several months before the outbreak of the Yom Kippur War (or the Fourth Arab-Israeli War) in October of the same year, the $\mathrm{WP}_{3}$ examined a New Oil Report issued by the OECD Oil Committee, which forecasted a scenario of rising oil prices. ${ }^{1}$ Inquiring into the oil price trend was among the institutional tasks of $\mathrm{WP}_{3}$, as rising oil costs could lead to balance-of-payments disequilibrium and a heavier reliance of industrialized countries on imported oil. The $\mathrm{WP}_{3}$ meeting brought to light some important points. First, on the basis of a set of forecasts of oil production and imports by region (i.e. North America, OECD Europe, Japan), including North Sea oil as well as domestic oil production in North America, the $\mathrm{WP}_{3}$ predicted an uneven impact of oil price rises. Its estimates, which included a serious increase in Japanese oil imports, turned out to be true. The share of oil in Japan's total imports, expressed in billions of yen, which stayed at I 5.7 percent in I973, almost doubled in I974 (30.3 percent) and reached a peak in 1980 after the second oil shock ( 37.5 percent). Although this share would decrease in the I980s owing to rising productivity and structural change of the Japanese economy (by I989 it had fallen back to I0.2 percent), oil imports were a predominant factor for Japanese imports in the second half of the I970s (Sugihara and Allan I993, p. 7). The $\mathrm{WP}_{3}$ forecasted also a divergence among North Atlantic economies, as the United States, still one of the largest producers of crude oil along with Venezuela, was relatively better protected against skyrocketing prices than the OECD European countries. This prediction, which was also fulfilled, would feed harsh discussions behind the scenes and a 'conspiracy theory' about the oil shock (Bini et al. 2016).

Second, and more importantly in a longer-term perspective, the $\mathrm{WP}_{3}$ Secretariat proposed a new approach to balance-of-payments aims. 'Most OECD countries have grown used to thinking that they should aim at having current account surpluses', but with the 'appearance of difficulty in such reconciliation', the Secretariat asked: 'Is the typical OECD country now going to accept a much smaller (or zero, or even possibly negative) current balance as a norm?' This question would further a discussion on balance-of-payments aims, which had been set as I percent of member countries' GNP. The oil shock, viewed from the $\mathrm{WP}_{3}$, would influence a rethinking of growth in relation to the balance of payments.

Third, the $\mathrm{WP}_{3}$ advanced an observation that would become crucial in the coming years: 'there are likely to be substantially greater uncertainties regarding the capital side of the account', other than the predicted balance-of-payments deficit. 'In practice, it will be very difficult to predict to which countries the flow will go or which forms it will take', after a huge movement of current accounts. The report concludes that

1 OECD Historical Archives (HA), CPE/WP 3 (73)I, 'OECD countries' balance of payments with the oil-producers, an outline of possible developments and problems up to I980' (note by Secretariat), Paris, 7 February I973. 
'Indeed, it is not only the destination of the flow of capital from oil producers, large as it seems likely to be, that would be at risk - but the stability of the entire stock, which, by I980, might be several times the then flow' (emphasis in the original text). ${ }^{2}$

Against this background, what outlook did $\mathrm{WP}_{3}$ formulate in February $\mathrm{I}_{973}$ for the Japanese economy in response to a prospective rise in oil price? 'Looking further ahead', the Secretariat wrote, 'the strengthening of Japanese competitiveness is probably a continuing trend', and 'net investment income must also be on a rising trend as a result of the growth of Japan's net asset position'. With these observations in mind, the $\mathrm{WP}_{3}$ expressed a 'wish to come back to the question of whether I percent of GNP is an appropriate current account aim'. The context was that 'given the attractiveness of Japan as a home for investment funds, may not liberalization of inward investment be accompanied by a significant return flow, e.g. from the oil producers?" 3 This statement was important in two respects. First, it was an attempt to revise existing balance-of-payment aims of member countries to limit their surplus or deficit within a band of I percent of GNP. Second, once the target of I percent of GNP was lifted, Japan was required to increase its imports and to allow a surplus of less than the I percent, in return for its capital market liberalization - in fact, for accepting petrodollars. This view was reinforced by a thorough country study on Japan, presented at a $\mathrm{WP}_{3}$ meeting held in April I973. Here the Secretariat projected Japan's current account surplus for I973 'to be larger than it would have been without the new realignment' under the Smithsonian Agreement of December I97I, ${ }^{4}$ and joined the US in its request to Japan to allow market opening on account of trade. ${ }^{5}$ The above discussions were representative of the attitude of OECD members toward a scenario of rising oil prices: the key point was revising the traditional approach to balance-of-payments aims, while fears of missing the target turned into criticisms against Japan for its rising trade surplus after the Smithsonian realignment.

The reaction of Japanese authorities, motivated by their traditional concern for the level of foreign reserves, was to maintain governmental regulations over capital flows (Takagi 20 I 5). However, the archival documents reveal that, despite the predicted rise in Japanese oil imports, within $\mathrm{WP}_{3}$ the rest of the OECD countries expected Japan to raise imports and cut exports in this early phase of the oil crisis. In other words, both sides focused on the balance-of-payments from a short-term perspective, without taking into account inflation or macro-economic performance. The discussion

2 Ibid

3 OECD-HA, CPE/ $/ \mathrm{WP}_{3}(73) 2$, 'Selective assessment of the international payments outlook' (note by the Secretariat), Paris, 9 February I973.

4 OECD-HA, CPE/ $\mathrm{WP}_{3}(73) 7$, 'Prospects for the transitional period, the factual background' (note by the Secretariat), Paris, I7 April I973.

5 OECD-HA, CPE/WP 3 (73)6, 'Prospects for the transitional period, issues for discussions' (note by the Secretariat), Paris, I3 April I973. 
analyzed in the following section, focused on the Eurocurrency market, reveals how the deepening of the oil crises made them change their mind.

According to the detailed study by Edoardo Altamura, the Eurocurrency market played a significant role in the recycling of petrodollars. Since the late I96os, voices calling for the regulation of the market had become louder, especially in international fora such as the BIS and the Gio. Japan, together with other major European countries, viewed with favor the idea of regulating this emerging international money market (Altamura 20I6; Yago 20I7). Also in the OECD $\mathrm{WP}_{3}$, in light of the new situation caused by the Nixon shock and the transition to a floating exchange rate system, the majority was rather favorable to restricting capital movement. ${ }^{6}$ However, after the unprecedented shock to oil prices and despite the fact that its impact was expected to vary across regions, the general attitude of the $\mathrm{WP}_{3}$ shifted toward the free-marketeers' thinking (Gray 2007, 2016; Gfeller 2012).

Under increasing pressure for market deregulation, the OECD held a $\mathrm{WP}_{3}$ meeting in October 1973 to revise its recommendations, taking also into account the new estimates of the Group of Oil Experts as well as the updated balance-of-payments forecasts drafted by the Secretariat. ${ }^{7}$ An exceptionally hot debate raged among participants, who included the US representative Paul Volcker, the $\mathrm{WP}_{3}$ chairman Otmar Emminger and the OECD official Robin Marris representing the Secretariat. Summing up the discussion, Emminger expressed a more positive view of the Eurocurrency market: 'In so far as it was invested in an anonymous and liquid form, e.g. in the Eurocurrency market, this might on the one hand accentuate the problem of large volatile funds, but could, on the other hand, also create opportunities to finance the deterioration in the overall balance of payments of some European countries.' The statement was important, as it signaled a move by the OECD away from a reluctant position to a more nuanced stance that emphasized the positive effect of the market in the adjustment of balance of payments.

In fact, petrodollar recycling through the Eurocurrency and the Eurocredit markets channeled a huge flow of funds toward oil-importing developing countries. This success silenced any further call for regulation of Eurocurrencies. European banks such as Barclays and Société Générale became the winners of the 'privatization of the recycling mechanism' (Altamura 20I6).

How did Japan react to this change? Japanese authorities were less sanguine about the virtues of market-based recycling and found themselves rather isolated. As a resource-poor country heavily dependent on oil imported from the Middle East,

${ }^{6} \mathrm{OECD}-\mathrm{HA}, \mathrm{CPE} / \mathrm{WP}_{3}(73)_{3}$, 'Exchange of views on capital controls' (note by Secretariat), Paris, 8 February I973.

7 OECD-HA, HT/73/I I.3, 'Summary of the discussion at Working Party no. 3's meeting on 29th/3oth October 1973', Paris, 25 November 1973, 
Japan wished to tighten its control over capital movements, since petrodollars did not flow into the Japanese market. Koichi Inamura, ${ }^{8}$ representing the Japanese Ministry of Finance at the $\mathrm{WP}_{3}$ meeting of October I973, clearly stated the Japanese position. Japan 'did not intend to ease the controls on capital inflows for the moment', and 'if there were any danger of capital inflows offsetting the effects of tight domestic monetary policy', the country would 'certainly maintain exchange controls'. The background of this blunt statement was that 'monetary and fiscal policy in Japan were at present concerned solely with internal considerations and with the problem of dealing with internal inflation'. ' Inamura's view stood on a notion, not clearly expressed at the $\mathrm{WP}_{3}$ meeting but rather described in his memorandum, that 'the back flow of the oil money would mainly go to the United States' and that in the case of Japan, such flow of oil money would be much smaller. Inamura, in his memorandum, even expressed the view that the 'United States was rather a beneficiary' of the situation. ${ }^{10}$ Inamura rightly understood the consequences of allowing free market-based recycling: the flow of oil dollars would be concentrated in the United States, which would be risky for Japan's foreign reserves and financial market. The oil shock strengthened the Japanese hard position on capital controls.

Meanwhile, a pessimistic mood toward the Eurocurrency market was creeping into the international debates on the oil crisis. In February I974, the Bank for International Settlements (BIS) presented a note entitled 'The oil situation and the euro-currency market' at the WP 3 meeting. ${ }^{11}$ At the beginning of the I970s, international institutions started to cooperate and exchange their documents simultaneously. The BIS report indicated that around 85 percent of foreign reserves of the oil-exporting countries were held in foreign currencies and that about a quarter of these foreign reserves had been deposited in the Eurocurrency market. Based on these figures, the BIS drew a somewhat gloomy picture with the following logic: (I) oil-importing countries with a large balance-of-payments deficit would borrow from the Euromarkets; (2) deficits would be financed by official reserves and by borrowing from other sources, especially from the US markets. In the case of the United States, the deficits could be covered by dollar liquidity, unrelated to the Euromarkets. (3) 'The actual impact on the world total expansion of bank credit will depend on how the Euro-banks dispose of their increased deposits.' The BIS report, which presented a

8 Koichi Inamura (I920-20I3) was in office as head of the International Affairs Division of the Ministry of Finance (I970-2), then Vice Minister of Finance for International Affairs (I972-4).

9 OECD-HA, HT/73/I I.3, 'Summary of the discussion at Working Party no.3's meeting on 29th/3oth October I973', Paris, 25 November I973.

${ }^{10}$ Bank of Japan Archives, OECD Keizai Seisau Iinkai oyobi dai 3, dai 4 Sagyoubukai tou [OECD Economic Policy Committee and the $\mathrm{WP}_{3}, \mathrm{WP}_{4}$, etc.], 5I-202, Gai no. 337, [memorandum] addressed to executive director Yukawa, 8 November I973.

11 OECD-HA, CPE/WP3(74)2, Paris, 5 February I974, Bank for International Settlements, 'The oil situation and the Euro-currency market' (note prepared for the meeting of Working Party 3 on I4-I 5 February I974). As for the BIS during the period, see Yago (2013). 
clear assessment on the size and trend of Eurocurrencies, was rather pessimistic toward the future working of the market, predicting a disturbing role played by the increasing credit supply of Eurobanks.

The Herstatt crisis and the other troubles in the Eurocurrency market during the second quarter of 1974 confirmed this pessimism. The $\mathrm{WP}_{3}$ suggested that the Euromarkets 'might be reaching saturation point'. ${ }^{12}$ Negative signals were plentiful in the $\mathrm{WP}_{3}$ report: 'The liquidity and profitability of many Euro-banks has been impaired by the switch of deposits away from small and medium-sized banks and the consortia banks.' Finally, the $\mathrm{WP}_{3}$ report shared the uneasiness expressed in the BIS report: 'From the outset, it was thought likely that the United States might emerge as a major intermediary for oil money.' The $\mathrm{WP}_{3}$ view on this channel of petrodollar recycling was twofold: 'This may be regarded as a desirable development in that the United States should be able to absorb large inflows of foreign funds more easily than other countries.' However, 'it presupposes the existence of adequate channels for the recycling of these funds on to other countries'.

The pessimism over the Eurocurrency market as a channel to recycle petrodollars was echoed simultaneously by the bankers who operated in the market. The Committee on Financial Markets, a specialized standing committee of the OECD composed of treasury and central bank representatives, held several meetings with private bankers in I974. At the third meeting held in March I974, the bankers unanimously expressed the view that 'difficulties for the Euromarket as a whole were unlikely to arise'. ${ }^{13}$ This optimistic view would be replaced by a serious sense of crisis four months later. At a similar meeting of the Committee with bankers, held in July I974, 'in contrast to the March meeting, there was much less optimism as to the ability of the international market to manage the bulk of the recycling problem'. 14

Now that the Eurocurrency market had become troubled, how did the Japanese authorities react? From the Japanese point of view, Eurocurrencies, and especially Eurodollars, were essential to finance growing imports. The Eurobanks, as cited above, were becoming conservative in mid I974, and in fact demanded a premium on the lending interest rate applied to Japanese borrowers. The premium, called 'Japan rate' or 'Japan premium', was about 2 percent, which became a harsh constraint on Japan's dollar funding. Facing the Herstatt crisis in June I974, the Japanese Ministry of Finance ordered Japanese banks to limit their short-term transactions in the Euromarket to below the amount held by the end of June I974, and banned mid-term and long-term lending in the market by the following month. The

12 OECD-HA, CPE/WP3(74)I6, 'Questions concerning recycling' (note by the Secretariat), Paris, I 8 September I974.

13 OECD-HA, CMF/M(74)3, Annex I, 'Summary record of the third meeting between members of the CMF and bankers', 6 March I974.

14 OECD-HA, CMF/M(74)3, Annex II, 'Summary record of the fourth meeting between members of the CMF and bankers', 3 July I974. 
$\mathrm{WP}_{3}$ observed: 'Early in July [I974], Japan modified its previous policy of fully financing its current account deficit through massive short-term foreign borrowing'; 'at the same time, they resumed depositing dollars with the commercial banks and slowed down the withdrawal of yen credit earlier extended to the banks for import financing. ${ }^{15}$ The Ministry of Finance, in retrospect, certified that 'in those days, the foreign exchange authorities had a sense of crisis that the Io billion-dollar foreign reserve was indispensable to maintaining international creditworthiness' (2004, p. 39).

However, Japanese action in this phase could be explained not only as the classical concern to protect foreign reserves. Two events provided the context: first, the overall balance-of-payments crisis in Europe and Japan, due to the oil shock, modified the approach to balance-of-payments aims; second, a new view emerged of the role Japan could play in the oil shock situation: a growth-enhancing role, summarized a few months later in the metaphor of Japan as a 'locomotive' for global growth.

As for the issue of the balance-of-payments, since the second half of I973, after the dollar depreciation the global trend and the context surrounding Japanese exports slowly changed. Unlike the optimistic forecasts of Japanese balance of payments published a few months earlier, the $\mathrm{WP}_{3}$ revised its projections: 'The large negative impact of commodity price increases on the Japanese current balance has roughly offset the "perverse" terms-of-trade effects of this year's appreciation of the yen.' The fall of nearly 4 billion dollars in the current surplus 'is somewhat larger than that expected at the time of the Smithsonian, probably as a result of cyclical factors and of the special trade measures taken by the Japanese authorities' ${ }^{16}$ This negative view of Japan's weak balance-of-payments position turned helped the Japanese delegates in their defense of capital controls and an exchange rate policy in favor of a cheaper yen. The decline in trade surplus was partly due to the strong trade ties between Japan and the United States, reflected in the high weight of the dollar in effective exchange rates calculated by the OECD Secretariat: this amounted to 44 percent for Japan, while it was below is percent for Continental Europe (Germany I 4 percent, France I I percent, the Netherlands 8 percent) and stood at I9 percent for the United Kingdom; the only country with a higher weight of the dollar was Canada (6o percent). ${ }^{17}$

What about the second issue, the so-called 'locomotive'? The issue appeared initially off the record, at a confidential meeting of finance ministers held in January I974. According to a report from the Bank of Japan's representative at the $\mathrm{WP}_{3}$, at the meeting '[Helmut] Schmidt proposed a meeting to discuss the conditions for export credit in February in Bonn, in order to avoid an excessive competition of

15 OECD-HA, CPE/WP3(74)I4, 'Capital flows and balance of payments financing' (note by the Secretariat), I7 September I974.

16 OECD-HA, CPE/WP 3 (73) I4, 'Working Party no. 3 of the Economic Policy Committee, current balances: evolution of the adjustment process' (note by the Secretariat), Paris, I 8 October I973.

17 OECD-HA, CPE/WP3(73)9, 'Working Party no. 3 of the Economic Policy Committee, recent developments in foreign exchange markets' (note by the Secretariat), Paris, 20 June I973. 
exports among member countries'. The $\mathrm{WP}_{3}$ chairman Emminger followed: 'Oil price increases have the effect of pumping up domestic liquidity on the monetary side and lessening demand on the material side with the transfer of monetary resources toward the high savings countries' on the one hand, but might lead to inflation 'with its cost-push effect'. Thus, the oil shock could bring about either a deflationary or inflationary effect. ${ }^{18}$ This statement by Emminger depicted two opposed possible scenarios for the post-oil shock, namely cost-push inflation in industrialized countries, on the one hand, and monetary deflation as a consequence of global capital movement, on the other.

At the $\mathrm{WP}_{3}$ meeting that took place soon after, in February I974, the Japanese delegates found themselves in a difficult position. Japanese representative Inamura noted that 'the general feeling of the meeting was that if the oil deficit endures after next year, the deficit itself should be decreased'. All representatives of member countries criticized the balance-of-payments overview presented by the Japanese delegate, with a deficit much smaller than that forecasted by the OECD Secretariat, which meant that Japan intended to strengthen its exports more than ever. Inamura reported 'strong wariness of the member countries to Japanese exports'. At the end of the meeting, Inamura proposed to hold the next $\mathrm{WP}_{3}$ meeting, due in April, in Tokyo. ${ }^{19}$ At that time, Emminger's proposal was yet to be shared among the participants.

At the $\mathrm{WP}_{3}$ meeting held in Tokyo on 18 and i9 April I974, Emminger stated that 'a decrease in import demand of a great power like Japan would be a constraint against world inflation. The Japanese tight monetary policy in this regard coincides with the global interest. ${ }^{20}$ At a new $\mathrm{WP}_{3}$ meeting held on $25-26$ June in Paris, the Japanese strategy was well received: 'The way that Japan manages domestic demand on the one hand, and finances the oil deficit in the Euromarket on the other, did not meet such strong criticism.' The major concern of the member countries shifted to the issue of where Japan would borrow outside the stagnating Eurodollar market. The Japanese delegate replied that the financing of Japanese imports would be raised mainly in the Euromarket and partly through American banks. Inamura explicitly stated: 'this is our traditional method of import finance: we need not and cannot shift the lending to mid and long term', as suggested by the peer members. Since 'raising

18 Bank of Japan Archives, [OECD Economic Policy Committee and the $\mathrm{WP}_{3}$, WP4, etc.], 5I-202, telephone call to the Foreign Division director, I7 January 1974, by Hayami. The sender of this report, Masaru Hayami (1925-2009), would become governor of the Bank of Japan (in office I998-2003).

19 Bank of Japan Archives, [OECD Economic Policy Committee and the WP 3 , WP4, etc.], 5I-202, Gai no. 66, OECD dai 3 Sagyoubukai ( $\mathrm{WP}_{3}$ ) no Moyou [On the meeting of the OECD-WP3], by executive director Yukawa, 27 February I974.

20 Bank of Japan Archives, [OECD Economic Policy Committee and the WP 3 , WP4, etc.], 5I-202, Gai no. I44, OECD dai 3 Sagyoubukai $\left(\mathrm{WP}_{3}\right)$ no Moyou [On the meeting of the OECD-WP 3 , by executive director Fujimoto, 22 April I974. 
bonds overseas was in fact impossible'. ${ }^{21}$ Given the crisis of the Eurocurrency market, Japanese delegates held to the course of turning Japan into an 'export great power'. The Japanese reply might have seemed a stand-alone position but was supported by Emminger: his idea of decreasing imports to put an end to world inflation, and instead to finance exports with credits from the Eurocurrency market and the American banks, made Japan a future locomotive of growth.

\section{IV}

With the easing of the initial oil price upsurge, the channel of petrodollar recycling seemed to stabilize during the months that followed. The inflow of petrodollars from oil-exporting countries into the Euromarket, especially in London, was reported in an impressive table (Table I).

Based on these data, the $\mathrm{WP}_{3}$ evaluated the role of the Eurocurrency market as follows: 'A large inflow of equilibrating capital into the OECD area' has 'offset roughly half the current account deficit of the area and greatly reduced the run-down of official reserves as well as the need to let exchange rates absorb some of the pressures'; 'a sizeable investment of official oil funds in the United States and United Kingdom money markets' has 'practically financed the official settlements deficits of these two countries'; and finally, 'the financial-intermediary (or recycling) role played by the United States and Euro-banks', so far 'have directly absorbed over half of the financial reflow from oil-exporting countries and financed a large proportion of the deficits of oil-importing countries'. ${ }^{22}$

In light of this pattern of petrodollar recycling, Japan worked out a new strategy. At a $\mathrm{WP}_{3}$ meeting held in Washington on 28 September 1974, which coincided with the IMF General Assembly, the consensus among participants was that private Eurobanks were constrained as far as the investment of oil money and the risk of maturity transformation were concerned. As a consequence, the ability of the Eurodollar market to recycle was approaching a saturation point. To cope with these risks, official or semi-official borrowing would be necessary. Building on this consensus, the Japanese delegate insisted (together with other members) that 'oil export countries would consider investing mid-term and long-term in the future', so that 'we should diversify the recycling channel'. However, 'direct borrowing or direct investment', as a method of diversification, 'might concentrate on a limited number of countries such as the United States'. In response to this comment, the US delegate noted that 'the foreign assets of the American banks increased by

21 Bank of Japan Archives, [OECD Economic Policy Committee and the WP 3 , WP4, etc.], 5 I-202, Gai no. 266, OECD dai 3 Sagyoubukai $\left(\mathrm{WP}_{3}\right)$ no Moyou [On the meeting of the OECD-WP 3 ], by foreign affairs director, 2 July I974.

22 OECD-HA, CPE/WP 3 (74) I9, 'Capital movements, the financing of deficits, and recycling', Paris, 6 November 1974 . 
Table I. External surplus and investment of oil-exporting countries (billions of US dollars)

\begin{tabular}{|c|c|c|c|c|c|}
\hline Investment in: & $\begin{array}{l}\text { I974 } \\
\text { I }\end{array}$ & $\begin{array}{l}\text { I974 } \\
\text { II }\end{array}$ & $\begin{array}{l}\text { I974 } \\
\text { III }\end{array}$ & $\begin{array}{l}\text { I974 first } 8 \\
\text { months }\end{array}$ & $\begin{array}{l}\text { I974 first } 9 \\
\text { months }\end{array}$ \\
\hline United States & I & 3 & 4 & $\begin{array}{r}7 \\
25 \%\end{array}$ & $\begin{array}{r}8 \\
23 \%\end{array}$ \\
\hline United Kingdom & 0.75 & I.25 & 2.25 & $\begin{array}{l}3 \cdot 5 \\
12 \%\end{array}$ & $\begin{array}{r}4 \\
11 \%\end{array}$ \\
\hline Eurocurrency market & 2.75 & 6.75 & 6 & $\begin{array}{r}\mathrm{I} 3 \\
46 \%\end{array}$ & $\begin{array}{l}\mathrm{I} 5 \cdot 5 \\
44 \%\end{array}$ \\
\hline of which in London & 2.5 & $4 \cdot 5$ & $3 \cdot 5$ & $\begin{array}{r}5 \\
33 \%\end{array}$ & $30 \%$ \\
\hline $\begin{array}{l}\text { Others (incl. international } \\
\text { organizations) }\end{array}$ & I & 3 & $3 \cdot 5$ & $\begin{array}{l}9.25 \\
18 \%\end{array}$ & $\begin{array}{l}10.5 \\
21 \%\end{array}$ \\
\hline Total external surplus and investment & 5.5 & I 4 & I6 & 28 & 35 \\
\hline $\begin{array}{l}\text { Increases in published official reserves } \\
\text { of OPEC countries }\end{array}$ & 4.5 & I I & 8.5 & $2 \mathrm{I}$ & 24 \\
\hline
\end{tabular}

Source: OECD-HA, CPE/WP3(74)I9, Paris, 6 November I974, 'Capital movements, the financing of deficits, and recycling'.

I, 500 million dollars since the beginning of the year', and this fact 'provides evidence of recycling to third-party countries'. Emminger commented: 'A considerable portion of that recycling may be flowing to the Japanese banks. ${ }^{, 23}$ The Japanese strategy, as expressed at this meeting, was to diversify the channel of recycling, either through the Eurocurrency market or by the American banks and bond markets, or even with direct recycling from the oil-exporting countries.

In fact, the presence of the Japanese banks became more and more visible in I974. Discussing the pattern of capital flows in the first quarter of $\mathrm{I}_{974}$, the $\mathrm{WP}_{3}$ Secretariat mentioned that 'for Japan, a substantial current account deficit of $\$ 3.3$ billion was more than offset by a capital inflow of $\$ 3.5$ billion. The main reason was a $\$ 4.4$ billion deterioration in the short-term external position of the Japanese commercial banks. ${ }^{24}$ Shortly afterwards, reviewing the trend in the first half of I974, the Secretariat reported that the external position of Japanese commercial banks, which caused an enormous capital account surplus of up to $\$ 7$. I billion, had jumped from $\$ 2.9$ billion to $\$ 8.4$ billion. 'Nearly all of this inflow was due to an increase in

${ }^{23}$ Bank of Japan Archives, [OECD Economic Policy Committee and the WP 3 , WP4, etc.], $5 \mathrm{I}-202$, Gai no. 303, OECD dai 3 Sagyoubukai $\left(\mathrm{WP}_{3}\right)$ no Moyou ni tsuite [On the meeting of the OECD-WP3], by foreign affairs vice director, I I October 1974.

${ }^{24} \mathrm{OECD}-\mathrm{HA}, \mathrm{CPE} / \mathrm{WP}_{3}$ (74) I I , 'Capital flows, monetary policies and the financing of payments deficits' (note by the Secretariat), Paris, I 4 June I974. 
Table 2. Major bank asset growth rates (1972-86)

\begin{tabular}{lcccc}
\hline \hline & $\begin{array}{c}\text { Bank asset } \\
\text { growth rate } \\
(\%)\end{array}$ & $\begin{array}{c}\text { GNP growth } \\
\text { rate (US\$) (\%) }\end{array}$ & $\begin{array}{c}\text { Total trade } \\
\text { growth rate } \\
\text { (US\$) }(\%)\end{array}$ & $\begin{array}{c}\text { Number of multinational } \\
\text { banking organizations } \\
\text { headquartered in the country }\end{array}$ \\
\hline France & I2.2 & I0.3 & I I.9 & 3 \\
Germany & I5.0 & 9.9 & I2.I & 4 \\
Japan & 20.9 & I5.0 & I9.I & 7 \\
UK & I3.I & 9.7 & II.5 & 7 \\
US & I0.I & 9.3 & I3.2 & 7 \\
\hline \hline
\end{tabular}

Source: Dohner and Terrell (I988), pp. 6, I7.

commercial banks' foreign liabilities in dollars, stemming from borrowing both in the US and in the Eurodollar market. 25

How strong was the Japanese banks' presence? Table 2, based on contemporary published statistics, gives an impressive picture. Although Japan and the United States had in common a sustained GNP growth, the growth rate of Japanese banks' assets was almost twice that of American banks. The table also shows that the fast growth of the Japanese economy had been triggered by trade. Using 1972 as a benchmark, data showed that the oil shock and its aftermath had brought about a successful expansion of Japanese banking and trade.

From Table 3, which summarizes foreign banks' presence in the United States in terms of total assets between 1972 and I978, one can see that the expansion of Japanese banks in the US market had been based more on their network of agencies rather than on branches and subsidiaries (unlike European banks). The two tables reflect their main strategies of internationalization in the I970s: (I) to establish consortia through a collaboration with securities companies, (2) to found local subsidiaries, and (3) to manage international syndicated loans. In fact, two consortium banks were set up in London in I970 by eight large-scale Japanese banks and four leading securities companies. Fierce competition ensued between the European and Japanese banks in search of international syndicated loans, and the Bank of Tokyo finally became the world's leading bank in loan syndications by 1978 (Igakura 2016, pp. IO3-5).

As regards the adjustment process, the $\mathrm{WP}_{3}$ in late 1974 came to notice that Japan was a strong country in terms of its initial balance-of-payments position (along with Germany), but weak in terms of its current dependence on imported oil (along with France, Italy and the UK). Taking into account the 'future dependence on oil or other energy imports', Japan's balance-of-payments problem was predicted to be 'particularly serious'. Moving from those premises, the $\mathrm{WP}_{3}$ set a less demanding

25 OECD-HA, CPE/WP 3 (74)I4, 'Capital flows and balance-of-payments financing' (note by the Secretariat), Paris, I7 September I974. 
Table 3. Total assets of US offices of foreign banks (Nov. 1972, May 1977, May 1978) (in millions of dollars)

\begin{tabular}{|c|c|c|c|c|c|c|c|c|c|}
\hline & \multicolumn{3}{|c|}{ Agencies } & \multicolumn{3}{|c|}{ Branches } & \multicolumn{3}{|c|}{$\begin{array}{c}\text { Subsidiary commercial } \\
\text { banks }\end{array}$} \\
\hline & $\begin{array}{l}\text { Nov. } \\
\text { I972 }\end{array}$ & $\begin{array}{l}\text { May } \\
\text { I977 }\end{array}$ & $\begin{array}{l}\text { May } \\
\text { I978 }\end{array}$ & $\begin{array}{l}\text { Nov. } \\
\text { I972 }\end{array}$ & $\begin{array}{l}\text { May } \\
\text { I977 }\end{array}$ & $\begin{array}{l}\text { May } \\
\text { I978 }\end{array}$ & $\begin{array}{l}\text { Nov. } \\
\text { I972 }\end{array}$ & $\begin{array}{l}\text { May } \\
\text { I977 }\end{array}$ & $\begin{array}{l}\text { May } \\
\text { I978 }\end{array}$ \\
\hline Japan & 8,766 & I 4 , IOI & I 4,540 & - & 4,386 & IO, 284 & $2, \mathrm{OI} 2$ & 5,648 & 7,005 \\
\hline Canada & 4,083 & 5,929 & 9,704 & 567 & 890 & I,6I 8 & 382 & 702 & I,075 \\
\hline Europe & 466 & 2,136 & 2,744 & 3,8 I 5 & I9,443 & 27,946 & $\mathrm{I}, 503$ & 8,096 & I I , 365 \\
\hline Rest of world & 320 & $2, \mathrm{I} 82$ & 3,823 & 730 & $2,74 \mathrm{I}$ & $4,64 \mathrm{I}$ & - & 720 & 869 \\
\hline All countries & I 3,365 & 24,348 & 30,8 I I & 5,302 & 27,459 & 44,488 & 4,064 & I $5, \mathrm{I} 66$ & $2 \mathrm{O}, 3 \mathrm{I} 2$ \\
\hline
\end{tabular}

Source: Terrell and Key (1978), p. 22.

balance-of-payments aim for Japan to take into account the fact that the oil effect could deal a hard blow to its external equilibrium. ${ }^{26}$ In other words, the OECD now viewed the role of Japan as a trigger of international growth, thus leaving some room for a balance-of-payments deficit instead of strictly tightening the economy for the sake of the balance of payments.

A year later, in 1975 , the discussion at the $\mathrm{WP}_{3}$ meeting over petrodollars had become more mature and well informed. In February I975, the OECD Secretariat estimated a long-term reserve position of oil-exporting countries. ${ }^{27}$ It concluded that, between I980 and I985, the OPEC members with a large population 'may not only have run down the real cumulative surplus they built in the latter part of the I970s but may also require a net capital inflow'. By this time, the OECD's view of Japan had become strongly growth oriented. When discussing the economic outlook of member countries for the near future, the general consensus was that 'a rebound of imports of the major countries would not come about before the second half of I975'. In this context, the Japanese delegate indicated that the Secretariat's forecast for domestic growth, ambitious as it was, was 'consistent with their own projection'. The $\mathrm{WP}_{3}$ members, including the Secretariat, expressed their concern 'as to whether present Japanese policy measures would be sufficient to achieve these growth rates', and Emminger asked the Japanese delegates 'to convey this concern to their authorities'. ${ }^{28}$ In a confidential memorandum attached

26 OECD-HA, CPE/WP3(74)20, 'Oil deficits and the adjustment process' (note by the Secretariat), Paris, 8 November I974.

27 OECD-HA, DES/NI(75)I, 'The medium term balance of payments implications of the oil situation' (note by the Secretariat), Paris, I7 February I975.

28 OECD-HA, Summary record of the meeting of Working Party no. 3, on I4-I 5 May I975, I4 July I975. 
to the official record of this session, the OECD economist Marris drew the attention of the $\mathrm{WP}_{3}$ to the need to pursue a growth policy, citing the Japanese case:

Take the case of Japan that we were discussing this morning. Are we quite sure that in our judgement of the prospects for Japan, we have fully taken into account the picture we have just been discussing on the developing countries? The developing countries are extremely important markets for Japan. And we have just agreed that the volume of their imports is falling sharply. Now has all that fully been taken into account? ${ }^{29}$

With his words, Marris wanted to emphasize that the consequences of a general decline in global economic activity for 'locomotive' countries should also be taken into account.

In the wake of, and shortly after the oil shock of $1973_{-4}$, three issues loomed large in $\mathrm{WP}_{3}$ debates. First of all, the international market for the recycling of petrodollars. Until the early I970s Japan had camped with the advocates of a regulation of the Eurocurrency market at the OECD and other international forums. After the oil shock, major European countries changed their mind and embraced the ideas of free marketeers. Japan, which still maintained restrictions over capital movements, was isolated. The archival records show that Japan stubbornly defended its position in favor of capital control: unlike the conventional view of Japan's silence in the international arena, the Japanese delegates at the OECD were keen to maintain their steady course despite hard criticism from other members. It is worth noting that this position did not necessarily stem from Japan's alliance with the US in the context of Cold War: in fact, Japan stood midway between the Americans and the Europeans in the debate on capital movements.

The second issue was the balance-of-payments adjustment. Severely hit by the oil shock, Japan was regarded as one of the weak countries in terms of external equilibrium. The $\mathrm{WP}_{3}$ paid attention to the worsening of the balance of payments and the foreign reserve position of Japan right after the oil shock. The main concern of the $\mathrm{WP}_{3}$ countries remained the fight against inflationary pressures generated by skyrocketing oil prices. The archival records demonstrate that the concern for the balance of payments, not only for Japan but for all OECD members, led to a revision of WP3's approach to the balance-of-payments aims. This was an important paradigm change for the OECD, which tried to steer growth of industrialized countries through planning and long-term aims setting. The softening of the aims approach under the impact of the oil shock would also suggest a reconsideration of the aggregate demand

29 OECD-HA, correspondence, S. N. Marris to members of Working Party no. 3, confidential, I 2 May I975. 
management supported by Keynesian economics, until then very influential within the OECD. The revision also implied a more explicit criticism of Japan's trade surplus.

The third issue, and the most important one for our research question, was the management of global growth. When the Japanese economy quickly regained sustained growth, other $\mathrm{WP}_{3}$ members did not hide their concerns for the role of Japan as an export giant, and criticized its exchange rate for being undervalued. However, in 1975 , their view changed, and they began to expect Japan to act as a trigger of international growth. Together with Germany and the United States, the Japanese economy was considered as one of the 'locomotives' that could lead the revival of economic growth in the West. In this context, the major concern of the $\mathrm{WP}_{3}$ shifted from how to tame Japanese exports to how to get Japan to import more, especially from the developing countries. The records of the Bank of Japan archives reveal that this change was initiated, at least within $\mathrm{WP}_{3}$, by Otmar Emminger. His view was that petrodollar recycling could have either an inflationist or a deflationist impact on the world economy. The role Japan was expected to play, following Emminger's proposal, became very demanding: to contribute to the global fight against inflation by keeping higher domestic interest rates, to enhance growth in the developing world by importing more from relatively poor countries, and finally to trigger international growth. Acting collectively as a strong banker, Japanese bankers and authorities diversified the channels for raising the necessary dollar funding.

Did Japan live up to the role it was expected to play after the first oil shock? The answer is yes: it became a 'locomotive' of world growth, together with Germany and the United States. While most European countries were fighting against inflation with higher domestic interest rates, Japan helped trigger a growth revival of industrialized countries. Japanese authorities' concerns over the scarcity of foreign reserves disappeared, the pessimistic view of a weak country heavily dependent on oil from the Middle East was overcome, and Japan even accepted the appreciation of a 'strong' yen as a tool for balance-of-payments adjustment. The start of a 'locomotive' policy was intimately connected to the search for solutions to petrodollar recycling, the balance-of-payments adjustment and global growth management. The process was much more complicated than the conventional view based on the 'American hegemony' (Spiro I999). Japan played (and was forced to play) a more prominent role in the world economy during and after the oil shock. An important point to reflect on here is that the whole process strengthened Japan's approach to capital movements, exchange rate management, state-led growth orientation and international banking strategies. In this sense, the 'Neoliberal turn' (Selva 20I7) did not reach Japan. The oil shock and its aftermath prompt us to rethink the role of Japan in contemporary financial history.

Submitted: I I April 2020

Revised version submitted: 6 May 2020

Accepted: I I September 2020

First published online: 5 November 2020 


\section{References}

ALTAMURA, C. E. (2016). European Banks and the Rise of International Finance: The Post-Bretton Woods Era. Abingdon: Routledge.

ASAI, Y. (20 I 5). The IMF and Japan: liberalization of foreign exchange and pursuit of high growth. In K. Yago, Y. Asai and M. Itoh (eds.), History of the IMF: Organization, Policy, and Market. Tokyo: Springer.

BELTRAN, A. (ed.) (20 I I). Oil Producing Countries and Oil Companies: From the Nineteenth Century to the Twenty-First Century. Oxford: Peter Lang.

BELTRAN, A., BUSSIÈRE, E. and GARAVINI, G. (eds.) (20 I6). L'Europe et la question énergétique, les années 1960/1980. Oxford: Peter Lang.

BINI, E., GARAVINI, G. and ROMERO, F. (eds.) (20I6). Oil Shock: The 1973 Crisis and Its Economic Legacy. London: I. B. Tauris.

CASSIS, Y. (2006). Capitals of Capital: A History of International Financial Centres, 1780-2005. Cambridge: Cambridge University Press.

DOHNER, R. and TERRELL, H. (I988). The determinants of the growth of international banking organizations: I972-86. International Finance Discussion Papers, 326, pp. I-64.

EICHENGREEN, B. and HATASE, M. (2007). Can a rapidly growing export-oriented economy exit smoothly from a currency peg? Lessons from Japan's high-growth era. Explorations in Economic History, 44, pp. 5OI-2I.

GALEAZZI, F. (20 I 5). La France et la réforme du système monétaire international (I96 I - I987): le rôle des experts du Groupe de Travail no. 3 de l'OCDE. PhD thesis, l'Université de Rouen.

GFELLER, A. (2012). Building a European Identity: France, the United States, and the Oil Shock, $1973-1974$. New York and Oxford: Berghahn Books.

GRAY, W. (2007). Floating the system: Germany, the United States, and the breakdown of Bretton Woods, I969-I973. Diplomatic History, 3I(2), pp. 295-323.

GRAY, W. (20I6). Learning to 'recycle': petrodollars and the West, I973-75. In E. Bini, G. Garavini and F. Romero (eds.), Oil Shock, the 1973 Crisis and Its Economic Legacy. London: I. B. Tauris

HOLLERMAN, L. (I979). Locomotive strategy and United States protectionism: a Japanese view. Pacific Affairs, 52(2), pp. I93-209.

IGAKURA, M. (20I6). Wagakuni toshiginkou no juusouteki kokusaika [Multilayered inter-nationalization of Japanese city banks]. Tohoku gakuin daigaku keizaigaku ronshu, I87, pp. 93-I I 8.

KOBORI, S. (20 Io). Nippon no enerugi kakumei: shigen shoukoku no kingendai [The Energy Revolution in Japan: Modern and Contemporary History of a Country with Limited Energy Resources]. Nagoya: University of Nagoya Press.

LEIMGRUBER, M. and SCHMELZER, M. (eds.) (20I7). The OECD and the International Political Economy Since 1948. London: Palgrave.

MAIER, C. (2004). Two sorts of crisis: the 'long' I970s in the West and the East. In H. G. Hockerts (ed.), Koordinaten deutscher Geschichte in der Epoche des Ost-West-Konflikts. Munich: Oldenbourg Verlag.

MINISTRY OF FINANCE [JAPAN] (2004). Showa zaiseishi: Showa 49-63 nendo [Financial History during the Showa Era, I974-I988], vol. 7. Tokyo: Toyo Keizai.

OECD (I964). Japan, Economic Surveys by the OECD. Paris: OECD.

SCHMELZER, M. (20I6). The Hegemony of Growth, the OECD and the Making of the Economic Growth Paradigm. Cambridge: Cambridge University Press.

SELVA, S. (20I7). Before the Neoliberal Turn: The Rise of Energy Finance and the Limits to US Foreign Economic Policy. London: Palgrave.

SHIRATORI, J. (20I 5). 'Keizai taikoku' Nihon no gaikou, enerugi shigen gaikou no keisei, 1967-1974. [The Energy Resource Diplomacy of a Rising Japan, I967-I974]. Tokyo: Chikura Shobo.

SPIRO, D. E. (I999). The Hidden Hand of American Hegemony: Petrodollar Recycling and International Markets. Ithaca, NY: Cornell University Press.

SUGIHARA, K. and ALLAN, J. A. (eds.) (I999). Japan in the Contemporary Middle East. London: Routledge.

SUZUKI, H. (2013). Ikeda seiken to kōdo seichōki no Nihon gaikō [Japanese Diplomacy during the High-speed Growth under the Ikeda Administration]. Tokyo: Keio University Press. 
TAKAGI, S. (2015). Conquering the Fear of Freedom: Japanese Exchange Rate Policy since 1945. Oxford: Oxford University Press.

TERRELL, H. and KEY, S. (I978). U.S. offices of foreign banks: the recent experience. International Finance Discussion Papers, I24, pp. I-25.

VAN LENNEP, E. (I998). Working for the World Economy: A Personal History. Amsterdam: Nederlands Instituut voor het Bank- en Effectenbedrijf.

WINAND, P. (I993). Eisenhower, Kennedy and the United States of Europe. Basingstoke: Macmillan.

YAGO, K. (20I3). The Financial History of the Bank for International Settlements. London: Routledge.

YAGO, K. (20I7). The crisis managers of the international monetary system? The rise and fall of OECD Working Party 3, I96I-I980. In M. Leimgruber and M. Schmelzer (eds.), The OECD and the International Political Economy since 1948. London: Palgrave. 